J. Asiat. Soc. Bangladesh, Sci. 38(1): 41-52, June 2012

\title{
FARMERS' PERCEPTION ON WATER RELATED ISSUES: A STUDY OF BHERAMARA UPAZILA, KUSHTIA
}

\author{
MD. HUMAYUN KABIR AND MD. FARUK HOSSAIN \\ Department of Geography and Environment, University of Dhaka \\ Dhaka 1000, Bangladesh
}

\begin{abstract}
Bheramara Upazila of Kushtia District, located in the southwestern part of Bangladesh is one of the most affected areas due to severe water flow reduction in the lower part of the Ganges (the Padma) which is seriously hampering agricultural production. The local people/farmers are tremendously suffering due to water related problems for their domestic as well as agricultural activities. The present study based on the primary field investigation (including open ended questionnaire interview with a total of 100 farmers), key informant interviews and direct field observation attempts to identify farmers' perception on water related issues and to understand the process, of how these problems are mitigated both in domestic and agricultural sectors.
\end{abstract}

Keywords: Water Issues, Farmer's Perception, Mitigation Measures, Bheramara Upazila

\section{Introduction}

Water is one of the most important natural resources being used in a variety of ways at many different levels (McDonald and Kay 1988). It is among the important requisites that nature provides to sustain life for plants, animals and humans. At the same time, water related problems are also becoming increasingly more and more interconnected with other development related issues and also with socioeconomic, environmental, legal and political factors, at local, national and sometimes at regional and even international levels (Biswas 2005). Bangladesh is, however, endowed with enormous water resources as it is crisscrossed by a large number of intricate (more than 200 rivers along with 54 common rivers with India and 3 with Myanmar) systems (Rasheed 2011). Although the country is recognized as the land of rivers on the globe, it has already experienced severe problems related to water scarcity in one of its major rivers, the Padma especially in the drier months. The country being located at the mouth of the lower end of the three great rivers (the Ganges, the Brahmaputra and the Meghna) has a deltaic fertile landmass. Among the three river systems the moribund part (southwestern region of Bangladesh) of the delta is totally dependent on the Ganges water (Rob et al. 2003). The Ganges, the most sacred of all the Hindus, rises west to the Nanda Devi Range in the Himalayas (Rashid 1991). The traditional source of the Ganges, however, is known as the Bhagirathi river that rises in India from the Gangotri glacier in the Himalayas at an elevation of more than 7,000 meters (Rasheed 2008). In 1975, after the commissioning of the Farrakka Barrage, the case of Indo-Bangladesh relations over the Ganges water sharing typically calls validity 
of this argument into question (Crow et al. 1995). Since the barrage was built by the Indian Government to divert the Ganges river water into the Hoogly river and to make the Kolkata port alive, it suddenly ceased significant water flow into the downstream in Bangladesh. Before the initiation of the project, it was largely felt by the Pakistani political leaders that inadequate water flow in the river channels would enhance siltation at river beds leading to the reduction of depth and navigability and increase proneness due to the rivers' retreating conveyance capacity. About 2.5 billion tons of sediments are annually carried to the Bay of Bengal through the Meghna estuary (Uddin et al. 2011). A part of the huge sediments is accumulated in the beds of major rivers resulting in the decrease of water level. Since water is crucial in the formation of so many phenomena, both living and non-living, it is not surprising that its diversion and use by humans would often cause environmental effects (Simmons 1993). However, the construction of Farrakka Barrage is basically responsible for water flow reduction in the lower part of the Ganges causing severe threats to a large number of people of the Ganges dependent areas (e.g., south and southwestern parts of Bangladesh). The gradual reduction of water flow in the river Padma has already caused severe social, economic and environmental problems in the downstream river basin especially in the moribund part of Bangladesh (Dewan and Nizamuddin 1999). It is reported that various environmental problems are often related to inadequate water quality that include sedimentation, saline intrusion and wetland and biodiversity loss (Ahmad 2000). After the construction of the Farrakka barrage, water flow in the Padma reduced remarkably and the lower part of the Ganges and its dependent area especially the southwestern region has been largely suffering (Crow et al. 1995). On the other hand, after the independence in 1971, the population of Bangladesh has been more than doubled. So, the competition over water use in fishery, agriculture, navigation etc. has enormously increased. The case of water related issues therefore, increases the conflict over trans-boundary river water. It then suggests that the conflict needs to be solved not only internationally on the Governmental level but also domestically within the particular local context of the affected areas. The local farmers of the present study area have already experienced many problems related to water use especially for agricultural production along with domestic use.

The present study attempts to understand local people's (areas those are located close to the Padma river) perception (especially the farmers' perception) regarding water related issues and the process of how the farmers are mitigating these problems both in household level and in agriculture. The present study can help us to understand and address of how and to what extent governance is functioning at a grass root level in rural life of Bangladesh. It can also be assessed with a particular reference to the role of local Government. Apart from the intervention by the central Government and bilateral negotiation about water sharing agreement, the roles played by the local Government are of great importance in addressing and mitigating the problems of the local people. The study on micro-level socio-political process can possibly explore the possibilities and limitations of the local Government in achieving more equitable resource allocation and 
forming the local basis of democratic governance over water. Another relevance of the study is related with the debate on the role of Non-Governmental Organizations (NGOs) and civil society in forming people centered-governance over resources and in consolidating democracy at a grass root level in Bangladesh.

In the context of Bangladesh, it is often argued that the active role of NGOs in this country reflects the weakness of the state and limited capacity of the Government to meet people's needs. It is also reported that NGOs activities are mostly limited in the private sphere of people's daily life and they hardly contribute to strengthen the state-society relations and thus to enhance democratic governance in this country. The study may also contribute to this debate on the role of NGOs and local Government in Bangladesh by exploring the scope of the role played by NGOs concerning water issues.

\section{Materials and Methods}

For the purposes mentioned above, a Participatory Rural Appraisal (PRA) technique was conducted in randomly selected two villages of the study area (Fig. 1) that are affected with reduced water flow from the Ganges. The PRA approach was helpful in identifying issues on water faced by the local farmers, and in cross-checking their opinions raised in the informal meetings. First of all, in order to understand the water crisis situation of the study area, a rigorous field observation was made by the study team. Informal group discussions with the farmers in the villages were also conducted, while various issues related to water scarcity were widely raised by the farmers. In the group discussions with the farmers, the local representatives and other key informants (for example, imams of mosques) also participated. The group discussions with farmers of different category have provided necessary and important information. Alongside, in order to have individual farmer's perception on water related problems, an open ended interview method was applied. A total of 100 randomly selected local farmers of several different categories (based on their level of income, education and age) of the study site were interviewed. Questions were mainly concerned with the present nature of the waterrelated problems, background and factors behind their emergence response taken by each category of people and changes in the nature and extent of the problems in course of social interaction. For the information, interviews were conducted among the farmers of different levels (elite/land owners, middle class farmers, small farmers, landless workers or tenant/share croppers and women as household heads). At the same time, local Union Parishad (UP) chairmen and members, elderly people/village matbors, imams, teachers of primary and high schools were interviewed with a view to cross-checking the water related issues as perceived by the farmers.

Study Site: Bheramara Upazila of Kushtia District is one of the most affected areas due to the reduction of water flow in the Ganges hampering serious agricultural production. Juniadaha Union of this Upazila has been purposively selected for the present study. 


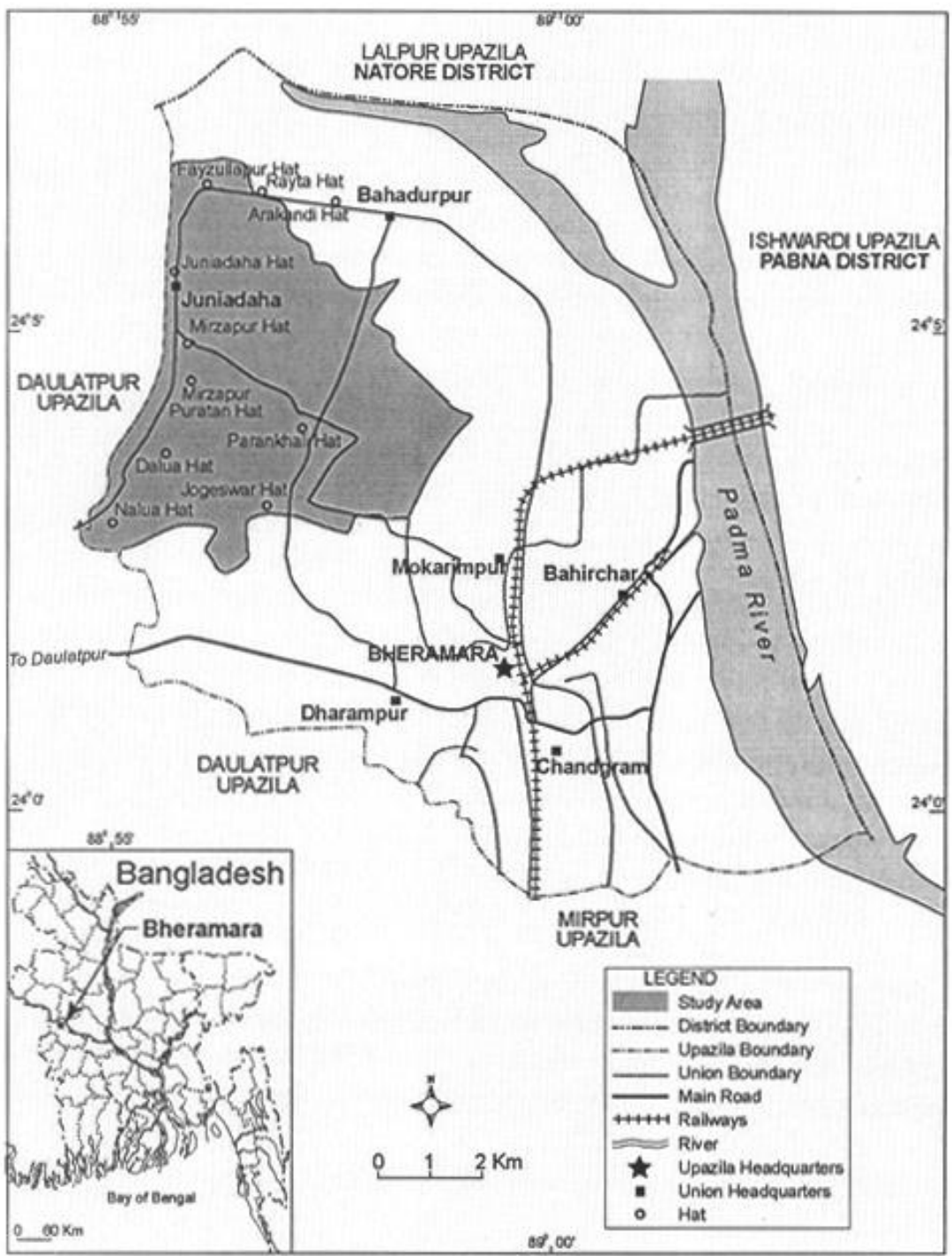

Fig. 1 Location of the Study Area

Geographically, the area is located in the south-western part of Bangladesh between $24^{\circ} 0^{\prime}$ and $24^{\circ} 10^{\prime}$ north latitudes and $88^{\circ} 55^{\prime}$ and $89^{\circ} 0^{\prime}$ east longitudes. The study site has an area of 7,544 acres (BBS 2007), and is very closely located to the river Padma (lower stream of the Ganges). One of the major distributaries (the Gorai) of the Padma is also very close to this region (Fig. 1).

Although the location of the union is very near to the big river, the farmers and the people of all levels are immensely suffering due to water related problems. Chemical fertilizers 
are often used in agriculture in the study area and lead to the deterioration of water quality. A large number of shallow tube-wells and deep tube-wells of Kushtia district are directly affected due to over withdrawal of upstream Ganges water (BBS 2005). Arsenic contamination of water has already been a threat to the domestic-level water users. The highest level of arsenic contamination is found in the large basin of the Padma and high concentration of arsenic in the southern and southwestern part of the country (Khuda 2001). Local people are also gradually being dependent on polluted pond water for domestic uses due to the decline of ground water table. The present study however, is an attempt to analyze the farmers' perception regarding water related problems and the mitigation strategies taken by the locals.

\section{Results and Discussion}

Emergence of Water Related Problems within the Study Area: The area started facing water related problems mainly after the Farakka Barrage was constructed in 1970 (Rasheed 2011). The severity of water scarcity in the study area started a few years later through the gradual rise of water demand especially for agriculture. In contrast, India continued to withdraw water at Farakka to the full capacity of the feeder canal in the dry season without any further understanding or agreement with Bangladesh. The Padma of Bangladesh experiences severe water flow problem during the lean season. In April 1976, the Ganges flows came down to only 23,200 cusec at Hardinge Bridge from the preFarakka flows of around 65,000 cusec (Rasheed 2008). It is evident that the 2,246 meter long Farakka Barrage, located $18 \mathrm{~km}$ upstream of Bangladesh near Mohonpur, has been a long lingering source of conflict and tension between Bangladesh and India (Rasheed 2011). Primarily, the barrage had two objectives, a) to maintain navigability of the Hoogly river and flush out the silt deposited in the Kolkata Port and b) to ensure saline free water supply for Kolkata City (Crow et al. 1995). However, the Bangladeshi Government tried to negotiate in different forums to ensure adequate flows of water in the Padma river but the situation could not be developed since that period. In the earlier period, monsoon water could enter in the study area due to the construction of embankments along the bank of the Padma river for which water sources declined. In the dry season, most of the ponds, canals and small rivers become dried up and ground water becomes the only source during this period.

Farmers' Problems over Water: Availability of water has been a valuable and scarce resource to people as well as to the farmers. Agricultural sector is severely affected due to water shortage in the dry season in the study area. In the present study, it has been observed that the farmers have to suffer both for irrigation and domestic usages (Table 1). In contrast, those who are relatively well-off have to invest a lot to withdraw ground water in the dry season through shallow-pumps. It has also been observed that the irrigation system of the study location is not well developed. Besides, many of the farmers are incapable of purchasing irrigated water and therefore, have to wait until the 
monsoon starts. Alongside, due to over-exploitation of the lands, their lands get infertile and require external inputs. In parallel with water scarcity for the agricultural crops, the farmers of the study area are also suffering from water for drinking and other domestic usage. As a result they often depend on the polluted pond water for the domestic purposes that eventually lead to high health risks. In the area, those who afford tube-wells for drinking water have also to encounter arsenic contamination.

Table 1. Water Related Problems Faced by the Farmers.

\begin{tabular}{lc}
\hline \multicolumn{1}{c}{ Problems (Agriculture) } & Number of Responses (\%) \\
\hline Water shortage for irrigation & $42(12.6)$ \\
Dependence on rain water & $36(10.8)$ \\
Incapable of purchasing water for irrigation & $31(9.3)$ \\
Irrigation system is not available & $29(8.7)$ \\
Rice is not cultivated timely due to lack of water & $26(7.8)$ \\
Do not get water for irrigation timely & $25(7.5)$ \\
The water level decreases & $22(6.6)$ \\
Soil fertility decreases & $18(5.4)$ \\
Increase of using chemical fertilizers & $28(8.4)$ \\
Less profit from agriculture due to unavailability of water & $20(6.0)$ \\
\multicolumn{1}{c}{ Problems (Domestic) } & $17(5.1)$ \\
Do not have tube-well water for drinking & $12(3.6)$ \\
Arsenic contamination & $10(3.0)$ \\
Water level decreases & $8(2.4)$ \\
Need to depend on polluted pond water & $6(1.8)$ \\
Do not get water timely from the shared tube-wells & $4(1.2)$ \\
No domestic problems & $334 *(100.0)$ \\
\hline Total (N=100) & \\
\hline
\end{tabular}

*Multiple answers were considered

Factors Causing the Water Issues: Various factors are responsible for creating water related problems in the study area. The water flow in the Padma has tremendously declined in the recent years, whereas water usage has rapidly increased with population growth. The inadequate supply of fresh water in the Ganges system due to upstream diversion threatened on irreversible environmental and agro-ecological damages in the study area. Within a few decade after the barrage was commissioned, water related issues have been identified as a national issue of Bangladesh. Climate change impacts such as fluctuations of rainfall are observed in the study area. In 1974 a total population of the study area was 17,230 (BBS 1977) and this figure has reached to 31,377 in 2001 (BBS 
2007). The rapid rise of population enormously increased the demand of water in the study location (Table 2).

Table 2. Factors Causing Water Related Problems.

\begin{tabular}{lc}
\hline \multicolumn{1}{c}{ Factors } & Number of Responses $(\%)$ \\
\hline The Padma river does not have enough water & $36(25.4)$ \\
The water usage has enormously increased & $32(22.5)$ \\
It does not rain timely in the rainy season & $24(16.8)$ \\
Farrakka barrage & $20(14.1)$ \\
Population have increased & $18(12.7)$ \\
Not aware of the factors & $12(8.5)$ \\
\hline Total $(\mathrm{N}=100)$ & $142 *(100.0)$ \\
\hline
\end{tabular}

*Multiple answers were considered

Farmers' Responses on Water Scarcity: The people of the study area are mostly involved in agriculture (31\%) (BBS 2007). The local farmers think differently when water related problems arise in the study area. The farmers usually change the cropping pattern when they face shortage of water. They try to create new sources of water and water usage techniques (Table 3). They cultivate those crops which require less water and sometimes they introduce new technology to fulfill the immediate demands of water. Local farmers try their best to make the availability of water to their fields. In some cases, they change their occupation and invest money in non-agricultural activities. The marginal farmers who used to cultivate for subsistence agriculture sometimes have to work as the day-laborers.

Table 3. Immediate Response of Farmers in Mitigating Water Issues.

\begin{tabular}{lc}
\hline \multicolumn{1}{c}{ Action/Responses by farmers } & Number of Responses (\%) \\
\hline Changes in crops to grow & $28(24.6)$ \\
Changes in cultivation & $25(21.9)$ \\
Changes in source of water and water use & $18(15.8)$ \\
Introduction of new technology & $16(14.0)$ \\
Changes in occupation and source of income & $15(13.6)$ \\
Investment in non-agricultural activities & $10(8.8)$ \\
Others & $2(1.8)$ \\
\hline Total $(\mathrm{N}=100)$ & $114 *(100.0)$ \\
\hline *Multiple answers were considered
\end{tabular}

Seasonal Migration due to Water Related Problems: Due to water related problems the farmers have to migrate seasonally from the study area to other places such asBheramara Sadar, Khustia, Dhaka City etc. in order to get employments. This situation 
happens almost in every year leading them to go outside their area for works. The farmers fail to manage their family needs from the agriculture. The hopeless farmers try to involve into other activities as they find difficulties to sustain their livelihoods in farming. It has been observed from the field that some of the farmers have to migrate seasonally due to crop failure. Besides, the agricultural production costs have remarkably increased in the recent years leading them to remain away from farming.

Further Problems Due to Water Shortage: The water shortage problems in the study area are increasing over time. Ground water is an important component of the water ecosystem in Bangladesh especially for domestic and irrigation requirements. Dependencies on ground water are rising at an alarming rate. Some surveyed areas are gradually becoming dependent on rain water. Farmers invest more money for fertilizer when they observe that the water supply is inadequate. Siltation could not occur regularly as the area is surrounded by dams which influence in declining soil fertility. In some areas soil colour has changed due to shortage of water. Ultimately, the production capacity of lands of the study villages has been dropping over time (Table 4).

Table 4. Further Problems Due to Water Shortage.

\begin{tabular}{lc}
\hline \multicolumn{1}{c}{ Further Problems } & Number of Responses (\%) \\
\hline Dependence on irrigation/ground water increases & $42(23.2)$ \\
Totally dependent on rain water & $35(19.3)$ \\
Use of chemical fertilizers increases & $34(18.9)$ \\
Soil fertility decreases due to lack of siltation & $28(15.5)$ \\
The soil colour has changed & $20(11.0)$ \\
Productivity of land decreases & $12(6.6)$ \\
Not aware of the problems & $10(5.5)$ \\
\hline Total & $181 *(100.0)$ \\
*Multiple answers were considered &
\end{tabular}

Role of Local Government: Local Government plays very little role to solve the water related problems in the study area. But it is very important to involve the representatives of the local Government for any kind of intervention in the community. In the farmers' opinions, no remarkable measures were taken by the local Government, while the local Government authority occasionally sets up new deep tube-wells to meet the demand (Table 5). The Department of Public Health and Engineering (DPHE) with the assistance of local Government distributes tube-wells among the inhabitants of the area. In parallel, they identify the arsenic contaminated tube-wells and encourage people to avoid using water from those tube-wells. The authority seldom dredges the surrounding canals to make the proper flow of water. Given the situation, the local Government has a pivotal role in maintaining supportive activities for the local farmers especially through 
providing tube-wells, making them aware of water usage, risk of using pesticides and fertilizers etc.

Table 5. Measures Taken by the Local Govt. to Mitigate Water Issues.

\begin{tabular}{lc}
\hline \multicolumn{1}{c}{ Measures taken } & $\mathrm{N}(\%)$ \\
\hline No remarkable measures taken & $40(27.3)$ \\
Set up new deep tube-wells & $35(24.0)$ \\
Trying to dredge the canal surrounded by the union & $32(21.9)$ \\
Provide tube-wells for each mahalla for drinking water & $23(15.8)$ \\
Trying to remove arsenic contaminated tube-wells & $1611.0)$ \\
\hline Total $(\mathrm{N}=100)$ & $146 *(100.0)$ \\
\hline *Multiple answers were considered
\end{tabular}

The Role of Central Government: The central Government does not provide any assistance to the farmers directly. It has been known from the farmers that they hardly receive agricultural goods (seeds, fertilizers, pesticides, equipments etc.) from the UP chairman. In this study, it has been known from the chairman that the central Government has a particular allocation for each union. Sometimes, the Union Parishad receives crop seeds, agricultural equipments etc. The UP chairman opined that the amount of goods they receive is not sufficient enough to satisfy all the farmers. The UP chairman also informed that the central Government is trying to provide sanitation equipments and set up arsenic free tube-wells at every household through the local elected representatives. On the other hand, the farmers opined that the central Government has seldom taken any initiative to solve the water related problems in domestic and agricultural sectors.

Improvement of Water Issues through Power Structure Change: Water resources of Bangladesh are characterized by a number of challenges and achievements. In ancient time, water was collected from dig wells and natural springs or artesian wells (where ground water in confined aquifers flows out on to the surface under hydrostatic pressure). In modern time, diesel and electric pumps withdraw water in larger quantities to supply the farmers as well as to whole population. In the study area, ground water is currently exploited for nearly $80 \%$ of the total cultivated land. It is extracted through both the shallow tube-wells (STWs) and deep tube-wells (DTWs) -the latter with depths of more than 100 meters and having a much larger command area. STWs are very popular among the farmers in Bangladesh, and the total number of STWs is now more than 450 and while there are about 40 DTWs in the area. The unreliable availability and fluctuating quality of surface water resources have prompted the authorities to start developing a groundwater supply system in the 1970s, installing wells in an effort to provide safe drinking water. Since arsenic was discovered in Chapai Nawabganj of Bangladesh, the local authority tried to mark the arsenic contaminated STWs and DTWs in the area and made some efforts to provide arsenic free water to the people. Government initiatives 
regarding water issues has also solved a considerable problems of water in the study area. Water supplies for agriculture will have to be increased by an additional 15 to $20 \%$ over the next 25 years, even after favourable assumptions regarding improvements in irrigation efficiency and crop yield performances.

Measures for Improving Water Related Issues: Farmers of the study area opined that water related problems should be solved without making any delay otherwise the whole community will be seriously affected. In certain cases, dredging of the rivers or khals may be beneficial but there is a tendency for dredged section to silt up. Dredging canal to connect with the Padma river was suggested by $25 \%$ of the respondents. Some of them $(22 \%)$ suggested digging new canals throughout the year to enhance the normal flow of water (Table 6). Huge number of new shallow and deep tube-well set up may be another solution. Hand tube-well (HTW) provide about $85 \%$ of rural population with potable water supplies (UNDP 1993). Some commented on opening the Farakka Barrage for a certain period of a year. The sitting Government should take effective measures to solve the water disputes between the neighbouring countries. A few of the farmers seems to be frustrated about the water issues. They think that the water problem is deteriorating gradually and situation will not be improved.

Table 6. Necessary Actions/Measures for Improving the Situation.

\begin{tabular}{lc}
\hline \multicolumn{1}{c}{ Actions/Measures } & Number of Responses (\%) \\
\hline Dredging canal to connect with the Padma River & $48(24.9)$ \\
Digging new canals to supply water through out the year & $42(21.8)$ \\
To set up new shallow and deep tube-wells & $38(19.7)$ \\
Farrakka Barrage should be opened & $30(15.6)$ \\
Government should take initiatives & $15(7.8)$ \\
This situation can not be improved & $12(6.2)$ \\
Do not know how to improve & $8(4.1)$ \\
\hline Total (N=100) & $193 *(100.0)$ \\
\hline
\end{tabular}

*Multiple answers were considered

The Role of NGOs: One way to contact local people and provide various types of services to the people is through NGOs. These organizations may also be of great assistance at solving the water related issues. Different NGOs are working in the study area to improve the water issue. The role of Grameen Bank, Bangladesh Rural Advancement Committee (BRAC), ASA, Prosika etc. are remarkable and they are providing loan facility to the local people for buying tube-wells, supplying and installing shallow and deep tube-wells. As the rain water is available in the monsoon period, BRAC recently has donated money and technical support in five places in the study area for rain 
water harvesting. These NGOs are trying to ensure the quality of water to the local people with the Government authority.

Farmers' Perception on Water Agreement Treaty of 1996: Since the partition in 1947, India and Pakistan (later Bangladesh) have been in conflict over their rights to use the water of the Ganges. Limited agreements between the two countries have reached, and some progress has been made toward effective and equitable utilization of the river (Crow et al. 1995). Bangladesh and India signed an agreement on the Ganges water sharing on 12 December 1996 for a period of 30 years. According to the Ganges Treaty of 1996, as a downstream country Bangladesh is supposed to receive a balance of flow in the case of maximum availability of water (75,000 cusec or more) (Rasheed 2008). Alongside, in case of the availability of 70,000 cusec or less, both Bangladesh and India should receive 50\% each. On the other hand, the farmers of the Ganges Dependent Area (GDA) are directly affected by the fluctuating flow of the Ganges water.

Table 7. Improvement of Water Related Issues after the Treaty in 1996.

\begin{tabular}{lc}
\hline \multicolumn{1}{c}{ Types of Change } & $\mathrm{N}(\%)$ \\
\hline No improvement has taken place & $56(56)$ \\
We get enough water in rainy season & $17(17)$ \\
Not aware of the treaty & $27(27)$ \\
\hline Total $(\mathrm{N}=100)$ & $100(100.0)$ \\
\hline
\end{tabular}

In the present study, it has been found that a remarkable number of farmers (56\%) opined that the agreement did not bring any improvement of water related issues after 1996. The second highest proportion of respondents $(27 \%)$ is not aware of the treaty and the least proportion of farmers $(17 \%)$ reported that they receive enough water in rainy season (Table 7). It can, however, be mentioned that the farmers severely suffer for water for various purposes whether the issues are well-perceived by most of them or not. The scarcity of water in the study area has also led significant number of farmers to migrate to different areas for works and to change their occupations. In contrast, there is hardly any assistance from the Government (local Government) and the NGOs towards the mitigation of the water related issues in the study area. In such a situation, the local farmers and villagers have to be provided with arsenic free tube-wells for safe drinking water and technologies to support agricultural practices. At the same time, the best solution will be to maintain normal water flow in the lower part of the Ganges. The regional cooperation of water sharing (e.g., existing water sharing treaty) therefore, has to be enhanced through bi-lateral negotiation, if the entire southwestern part of the country has to survive. 


\section{References}

Ahmad, Q.K. 2000. Bangladesh Water Vision 2025: Towards a Sustainable Development World, Bangladesh Water Partnership, Dhaka, 13 pp.

BBS, 1977. Bangladesh Population Census, 1974, Village Population Statistics, Kushtia District, Bangladesh Bureau of Statistics, Statistical Division, Ministry of Planning, Government of the People's Republic of Bangladesh, 85. pp.

BBS, 2005. Handbook on Environment Statistics 2005, Bangladesh Bureau of Statistics, Statistical Division, Ministry of Planning, Government of the People's Republic of Bangladesh, p. $141,150$.

BBS, 2007. Bangladesh Population Census, 2001, Community Series, Zila-Kushtia, Bangladesh Bureau of Statistics, Statistical Division, Ministry of Planning, Government of the People's Republic of Bangladesh, 120. pp.

Biswas, A.K., 2005. Integrated Water Resources Management: A Reassessment, Oriental Geographer. 29(2): 59-76.

Crow, B., A. Lindquist and D. Wilson. 1995. Sharing the Ganges: The politics and Technology of River Development, University Press Limited, Dhaka, 124-137 .

Dewan, A.M. and K. Nizamuddin, 1999. Impact of Ganges Water Diversion on the Southwest Part of Bangladesh: A Perception Study, BIISS Journal. 20(2): 138-160.

Khuda, Z.R.M.M. 2001. Environmental Challenges of the $21^{\text {st }}$ Century, Environmental Survey Research Unit, Dhaka, 150. pp.

McDonald, A. and D. Kay. 1988. Water Resources Issues and Strategies, John Wiley \& Sons, Inc., New York, p. 1.

Rasheed, K.B.S. 2008. Bangladesh: Resource and Environmental Profile, AH Development Publishing House, Dhaka, 36-54. pp.

Rasheed, K.B.S. 2011. Water Resources Management: With Examples from Bangladesh, AH Development Publishing House, Dhaka, pp. 37-49.

Rashid, H. Er. 1991. Geography of Bangladesh, University Press Limited, Dhaka, 58 p.

Rob, M.A., R.H. Bhuiyan and S.A. Mamun, 2003. Morphological Changes of the Padma-Meghna Confluence of Bangladesh, Oriental Geographer, 47(2): 1-12.

Simmons, I.G. 1993. Earth, Air and Water: Resources and Environment in the Late $20^{\text {th }}$ Century, Edward Arnold, London. 93-103. pp.

Uddin, M.J., M.S. Hussain,, A.K. Taraqqi and A.S.M. Mohiuddin, 2011. Intensification of Landuse in the Coastal Land Offshore Areas of Bangladesh, Oriental Geographer, 52(1\&2): 6777.

UNDP 1993. South East Region Water Resources Development Programme, Action Plan (FAP) 5, Regional Plan Report, Vol. 1, Part-1, Existing Situation, United Nations Development Programme, Dhaka, 4-11. pp. 